\title{
Effectiveness Identification Number Filing for Solutions to Accelerate in Complete Systematic Land Registration Program (PTSL) in Blora District Land Office
}

\begin{abstract}
Anis Ayu Rahmawati ${ }^{1}$, Deni Dwi Noviandi ${ }^{2}$ and Achmad Sulchan ${ }^{3}$
Abstract. Blora Regency is one of regencies in Central Java conducting simultaneously the Complete Systematic Land Registration Program (PTSL) whose responsibility is delegated to the National Land Agency (BPN) Blora. In doing filing related to the file recapitulation, BPN Blora create a policy for the provision of Parent Number meantime to ease the recapitulation of the field which will be registered in PTSL. The purpose of this study was to analyze the Complete Systematic Land Registration Program (PTSL), factors that become obstacles in the implementation of PTSL and to determine the policy of the Master Numbers While (NIS) as a solution Blora District Land Office in the implementation of PTSL.

The method used in this research is juridical empirical specification is descriptive analytical research and data collection was obtained from library research and interviews. After data collection is done, then the data is analyzed qualitatively.

It can be concluded that the implementation of Complete Systematic Land Registration Program (PTSL) has many constraints among which the cost of land tax payable, the limited number of human resources and infrastructure, land disputes absente, maximum advantages and wastelands and the difficulty of applying the principle of contradictoire delimitatie. To overcome these obstacles BPN Blora do some solutions, among others, added the officer measurement with tool support, expand facilities and infrastructure, especially computers and printers, repair Internet network as well as the policy of Identification Number While (NIS) as a solution to the District Land Office Blora in the implementation PTSL that facilitate more efficient file search.

Keywords: Land Registration; Identification Number While (NIS); PTSL.
\end{abstract}

\section{Introduction}

Soil is the potential of the country that was instrumental in supporting development. Tenure is essentially a reflection of mankind's view of himself as a man in relation to the ground. Man's relationship with the land raises the authority and responsibility for the welfare of yourself and others. So should the use of the function of the earth and water, as well as the natural riches contained therein is aimed to achieve the greatest prosperity of all the people of Indonesia. As in article 33, paragraph 3 of the 1945 Constitution which reads earth and water and natural resources contained in it are controlled by the state and used for the prosperity of the people ${ }^{4}$,

The purpose of the Government in the implementation of land registration, among others to provide legal certainty and legal protection to the owner or holder of the land rights of a plot, apartment units, and other rights registered in order to easily be able to prove himself as the holder of rights concerned and for the implementation of the orderly administration of both the Village, Village and the level of the land office. ${ }^{5}$

\footnotetext{
${ }^{1}$ Students of Master of Notary Law Faculty of Law, Universitas Islam Sultan Agung email anishmasrur5657@gmail.com

2 Students of Master of Law, Faculty of Law, Universitas Islam Sultan Agung email bbony77@yahoo.com

${ }^{3}$ Lecturer in Faculty of Law UNISSULA Semarang

${ }^{4}$ Law of the Republic of Indonesia Number 5 of 1960 concerning provisions Agrarian

${ }^{5}$ Indonesian Government Regulation Number 24 of 1997 on Land Registration
} 
One of the goals in ruled of BAL is to guarantee legal certainty. These objectives can be realized through two efforts, namely ${ }^{6}$ :

- Availability of a legal instrument in writing, fully and clearly implemented in a manner consistent with the spirit and provisions, and

- Implementation of land registration that allows for holding the titles to easily prove title to the land under its control and for interested parties such as prospective buyers and prospective lenders, to obtain necessary information about the land which became the object of legal act performed as well as for the government to implement land policy.

Less or lack of data on land ownership became one of the causes of the lack of land rights registration process. Another thing is the cause of that is also the lack of public awareness of the importance of the sense of proof of ownership of land rights. For the process of making the certificates they must have complete papers for the land they own, but in fact the lands owned by the community, especially rural or indigenous peoples are many who have for generations of their ancestors, so that their land titles have very minimal and some have none at all, but physically have mastered.

Government Regulation No. 24 of 1997 is one of the operational conduct sistematically registration, by registering all parcels of land in a region of villages or so. Registration this way is considered to provide maximum results within a relatively short, because data collection registration simultaneously in all the fields in a rural / urban.

Land Registry Systematic Complete (PTSL) is a land registration activities for the first time carried out simultaneously covering all the objects of registration of land which has not been registered in an area of the Village and also includes equal distribution of all objects of land registration that has been registered in order menghimoun and provide information complete the areas of land.

Blora is a district with an area of $1820.59 \mathrm{~km}^{2}$, is the greatest use of their area as a forest which covers state forests and private forests, namely $49.66 \%, 25.38 \%$ paddy land and the rest is used as a yard, fields, reservoirs, smallholder and others ie $24.96 \%$ of the total land use. ${ }^{7}$ Blora Regency is one of regencies in Central Java conducting simultaneously PTSL whose responsibility is delegated to the National Land Agency Blora. Five hundred (500) pieces of land into an object PTSL, and in the 2018's, the target increased to 44,000 parcels of land in 50 villages targeted. ${ }^{8}$ PTSL with the number of objects that are not small, it is not uncommon pose an obstacle for the National Land Agency Blora in doing filing. To overcome this, in doing filing related to the file recapitulation, the National Land Agency Blora create a policy for the provision of Parent Number meantime to ease the recapitulation of the field which will be registered in PTSL. Based on the description above and to determine the full implementation of systematic land registration in Blora, the authors are interested in doing research in the title "Effectiveness Identification Number Filing For Solutions To Accelerate In Complete Systematic Land Registration Program (PTSL) In Blora District Land Office".

Based on the description above, the problem in this research are:

- How to Complete Systematic Land Registration (PTSL) in Blora District Land Office?

- What are the factors that become problems in the implementation of PTSL?

- How to policy administration Whilst Identification Number (NIS) as a solution Blora District Land Office in the implementation of PTSL?

\footnotetext{
${ }^{6}$ Boedi Harsono 1999 Hukum Agraria Indonesia: Sejarah Pementukan Hukum Agraria Isi dan Implementasi Ed.Rev. Cet. $8^{\text {th }}$ Djambatan Jakarta p. 69

${ }^{7}$ http://www.blorakab.go.id/index.php/public/profil/index/164 accessed on October 2 11:40 AM

${ }^{8} \mathrm{http}: / /$ www.infoblora.com/2017/11/lurah-kades-harus-menyukseskan-ptsl.html accessed on 02 October at 12:10
} 
The method used in this research is Empirical Juridical. Specifications of this research is descriptive. The collection of data obtained from library research. ${ }^{9}$ It also obtained through interviews held a question and answer orally and directly, with the parties directly related to the issues under investigation. Data analysis technique used is qualitative analysis. ${ }^{10}$

\section{Results And Discussion}

\subsection{Complete Systematic Land Registration Program (PTSL) in Blora District Land Office}

Land Registry Systematic Complete is a land registration activities for the first time carried out simultaneously for all objects of land registration throughout the territory of the Republic of Indonesia in the territory of the village / village or other names that level with it, which involves the collection and determination of the truth of physical data and juridical data regarding one or several objects of registration of land for the purposes of registration. ${ }^{11}$ Interest accelerated implementation of land registration systematically complete is to accelerate the provision of legal certainty and legal protection rights of society as a definite, simple, fast, smooth, safe, fair, equitable and open and accountable, so as to improve the welfare and prosperity of society and the country's economy, as well as reduce and prevent disputes and conflict over land. ${ }^{12}$ Complete Systematic Land Registration Program (PTSL) held the Ministry of ATR / Ka. BPN targeting 126 million parcels of land in Indonesia registered and certified overall in 2025. Later translated into targets 5 million field in 2017, 7 million field in 2018, 9 million field in 2019 and 10 million each year until 2025. Targets PTSL this is not an easy job, many people think only of ambition, imaging, and short-term political interests, because this notion refers to the land registration results have been less than 50 percent of the land that is already registered. Though already 57 years ago commands obliged to register their land as has been mandated by the BAL. When analyzed more deeply the main cause is the political will of governments, land registration programs previously carried out at the level of ministries and not the government as the highest peak of the President. Normatively regulated in the legislation as a means of facilitating and accelerating the land registration throughout Indonesia.

Complete Systematic Land Registration Program (PTSL) National Agricultural Program (Prona) Blora district land office to get a quota of 25,000 field in 2017. Initially budget BPN 15000 Blora get quota field. Then get an extra BPN 10,000 Center field. So overall total of 25,000 fields. The village that the administration had received land certificates that Kalen village kedungtuban subdistrict. The total quota for the 2017 budget year is 25,000 Blora field. ${ }^{13}$

To improve the quality of spatial planning in Indonesia, the Ministry of Agricultural and Spatial Planning / National Land Agency has launched a Geographic Information Systems Spatial (GISTARU) that everyone can access the spatial plan applicable national and applicable in every area. With the opening of access to documents of spatial planning, is expected to increase public awareness and further the community play an active role in the process of drafting the spatial plans and monitoring their implementation. With regard

\footnotetext{
${ }^{9}$ Soerjono Soekanto and Sri Mamudji 1995 Penelitian Hukum Normatif Rajawali Press Jakarta p.39

${ }_{10}$ Bambang Sunggono 1997 Metodologi Penelitian Hukum Raja Grafindo Persada Jakarta p.10

${ }^{11}$ Article 1 paragraph (2) of Regulation of the Minister of Agrarian No. 12 of 2017

${ }^{12}$ Article 2 paragraph (2) of the Regulation of the Minister of Agrarian No. 12 of 2017

${ }^{13}$ Interview with Mudjiono head of BPN Blora August 8th 2018
} 
to the legalization of assets through Complete Systematic Land Registration Program (PTSL) the number of parcels throughout Indonesia \pm 126 million parcels is expected in 2025 the whole plot had been registered. This includes land in Blora. ${ }^{14}$ To carry out the acceleration of Complete Systematic Land Registration Program (PTSL) is needed to optimize the use of the latest technology, in line with the modernization of services in the Ministry of Agricultural and Spatial Planning / National Land Agency.

\subsection{Factors to be issues in the implementation of PTSL}

In the implementation of PTSL in Blora, Blora BPN while various problems, such as:

\subsubsection{Fees payable to Land Tax}

Fees payable to Land Taxes include income tax and BPHTP. The financing of this PTSL can be sourced from the state budget, budget, Bulk Certificate of Governmental and Corporate Social Responsibility (CSR) state, enterprises, and private. Reinforced with Joint Ministerial Decision ATR / Ka. BPN, Minister of Home Affairs, and Minister for Rural, Rural Development and Transmigration No. 25 / SKB / V / 2017, No. 590-3167A year, 2017, No. 34 Year 2017 on Financing Preparation Systematic Land Registration. Financing activities related to the preparation of the document, stilt procurement activities and operations officer Stamp and the urban / rural, these costs are not included BPHTB and income tax expense. BPHTB costs associated with Interior Minister ordered the regent / mayor to provide a reduction and / or relief or exemption BPHTB. Terms of the income tax expense, BPHTB, and deed are one of the major factors inhibiting the registration of land. During this time the impression of the public to take care of the certificates was expensive, long and convoluted. Cost is expensive because it must pay the deed, Income Tax, and BPHTB, a long process due to take time to take care of certificates, paying taxes, and administrative processes in BPN, hogging must back and forth to the office of PPAT, the Tax Office Pratama, and the Office of National Revenue, Finance and Asset and BPN.

To overcome these problems can be done through the process of land certificate one roof, in a way, all these processes of the BPN (eg, PPAT Tax Office and there is a separate space in the Land Office), which can affect the public interest in the land register. Likewise, the problem PPhb and BPHTB payable in PTSL execution set out in Article 33 of the Regulation of the Minister of ATR / Ka BPN No. 6 Year 2018, which provides ease of implementation space PTSL program, for which they are not able to pay income tax and BPHTB to make a statement and BPHTB income tax payable.

\subsubsection{The limited number of Human Resources and Infrastructure}

The successful implementation of PTSL determined by the quality of human resources. Number of human resources and employment must be in balance and concomitantly. Lack of qualified human resources can also be seen from masi number of extortion committed by the conduct PTSL in Blora. Like the case of extortion committed by Kawengen village chief, who was arrested in August 2018 Officer yesterday, guilty of extortion in PTSL implementation of 40 million. ${ }^{15}$ Besides the limited facilities and infrastructure owned by BPN Blora which is associated with tech measuring devices, the Internet, computer, printer, and the limited capacity of the office where the product yield management PTSL lot. Thus the necessary budget and cooperation with local governments related to the problems.

\footnotetext{
${ }^{14}$ Interview with Mr. Djoko Nugroho Regent Blora October 232018

15 http://daulatdesa.com/2018/08/13/selewengkan-ptsl-oknum-kades-kawengan-blora-diciduksaber-pungli/ Accessed October 252018
} 


\subsubsection{Absente land problems, the maximum advantages and wastelands}

Absente Land is land ownership outside the range of their owners. In Blora there are problems absentee land. Though absentee land itself prohibited by Article 10 of the BAL. Similarly, the ban on the ownership and control of land beyond the limit (Article 7 BAL) as an effort to prevent the accumulation of land in the hands of certain groups only. As well as the prohibition of abandoning the land (Article $27 \mathrm{BAL}$ ). The fact is happening on the ground there are still many people who own agricultural land in the land of absentee and aggressors, and abandon their land.

\subsubsection{The difficulty of applying the principle of Contradictoire Delimitatie}

Contradictoire elimination principle is the principle governing the determination of the boundaries of plots of land by agreement of the parties. If the land owners bordering not obtain an agreement with the actual position of a boundary despite the application of mediation, then setting boundaries with pengangadilan decision (Articles 17, 18, 19, Regulation No. 24 of 1997). Therefore, the agreement / consent and presence of neighboring land owners is an obligation in the land registry. The application of this principle not yet run well in Blora. It is caused by several factors, namely:

- Land-rights holders do not maintain a good ground plane boundaries, no clear plot or limits have been fitted with the pin missing, lack of public awareness to maintain boundary markers

- The parties are not present at the time of the delimitation of the land, because of busy landowners and landowners or difficult to find due to absentee land ownership

- Third, the land boundary disputes, family disputes and disputes or neighbor who has entered the realm of the courts.

These problems have become an obstacle to the measurement process. For that socialization in the form of outreach to the community is very important to do, especially in terms of establishing, placement and maintenance of land boundaries. ${ }^{16}$

\subsection{While the policy of Identification Number (NIS) as a solution in Blora District Land Office in the implementation of PTSL.}

In doing filing related to the file recapitulation, the National Land Agency of Blora create a policy for the provision of Parent Number meantime to ease the recapitulation of the field which will be registered in PTSL. Pre-filing stage is the stage of certification. While granting Identification Number (NIS) also facilitates the search data in the computer, so it can save time and effort, so that the certification process can be run efficiently. For further requirements that must be met in PTSL are:

- Physical Data (Land and the limit should be clear)

- Data Juridical (other supporting data)

Land Registry Systematic Complete conducted simultaneously for all objects of registration of land in the entire territory of the Republic of Indonesia in the territory of the village of village or any other name that is level with it, which involves the collection and determination of the truth of physical data and juridical data regarding one or more objects of registration of land for purposes registration. ${ }^{17}$

\footnotetext{
${ }^{16}$ Interview with Mr. Susilo Staff BPN Blora October 232018

${ }^{17}$ Article 1 point 1 Regulation of the Minister of Agrarian No. 12 of 2017
} 


\section{Closing}

\subsection{Conclusion}

From the research can be summarized as follows:

- Complete Systematic Land Registration Program (PTSL) in Blora District Land Office Complete Systematic Land Registration Program (PTSL) National Agricultural Program (Prona) Blora district land office to get a quota of 25,000 field in 2017. Initially budget BPN 15000 Blora get quota field. Then get an extra BPN 10,000 Center field. So overall total of 25,000 fields. The village that the administration had received land certificates that Kalen village kedungtuban subdistrict. the total quota for the 2017 budget year is 25,000 Blora field.

- Factors to be issues in the implementation PTSL

- Fees payable to Land Tax

- The limited number of Human Resources and Infrastructure

- Absente land problems, the maximum advantages and wastelands

- The difficulty of applying the principle of Contradictoire Delimitatie

- While the policy of Identification Number (NIS) as a solution Blora District Land Office in the implementation of PTSL.

In doing filing related to the file recapitulation, the National Land Agency Blora create a policy for the provision of Parent Number meantime to ease the recapitulation of the field which will be registered in PTSL. Pre-filing stage is the stage of certification. While granting Identification Number (NIS) also facilitates the search data in the computer, so it can save time and effort, so that the certification process can be run efficiently.

\subsection{Suggestion}

- BPN Blora should improve its performance in giving information and services to the public about the importance of the implementation of PTSL.

- People should be more open with information and rules of the law of the land.

\section{Bibliography}

[1] Bambang Sunggono 1997 Metodologi Penelitian Hukum Raja Grafindo Persada Jakarta.

[2] Boedi Harsono 1999 Hukum Agraria Indonesia: Sejarah Pementukan Hukum Agraria Isi dan Implementasi, Ed.Rev., Cet. $8^{\text {th }}$, Djambatan, Jakarta.

[3] Soerjono Soekanto and Sri Mamudji, 1995, Penelitian Hukum Normatif, Rajawali Press, Jakarta.

[4] http://www.blorakab.go.id/index.php/public/profil/index/164 accessed on October 2 11:40 AM

[5] http://www.infoblora.com/2017/11/lurah-kades-harus-menyukseskan-ptsl.html accessed on 02 October at 12:10

[6] http://daulatdesa.com/2018/08/13/selewengkan-ptsl-oknum-kades-kawengan-bloradiciduk-saber-pungli/, Accessed October 25, 2018

[7] Indonesian Government Regulation Number 24 of 1997 on Land Registration

[8] Law of the Republic of Indonesia Number 5 of 1960 concerning provisions Agrarian

[9] Regulation of the Minister of Agrarian No. 12 of 2017 